\title{
Research on Different Types of Cracks in Plain and Reinforced Concrete
}

\author{
Snehal Abhyankar
}

\begin{abstract}
Study of different types of cracks in plain and reinforced concrete subjected to environment full of chloride and carbon laden corrosion problems. It is the most critical global challenge for construction industry which incurred losses more than \$100. Cracks are ubiquitous in concrete materials and can destabilize a concrete structure, regardless of size or type. What happens structures are subjected to continuous loading.The study of behavior of structure for development of cracks which may be horizontal, vertical, to cracks possess little fracture energy. While discussing factors affecting cracking corrosion rate is key factor. An accurate method for measuring crack characteristics is presented. Analyzing results show that curves to be plotted for behavioral pattern for crack propagation. The construction industry demands such model to show serviceability of corrosion prone buildings or structures. . RCC structures life can be enhanced by proper maintenance and repairs. . Structures may cause matrix cracks, loading at variable speed due to non adherence of materials . Results studied were analyzed and rechecked by creating simulations of models. Increasing crack width and length lead to new study of infinite plate.
\end{abstract}

Keywords: cracks, concrete, crack length, crack width.

\section{INTRODUCTION}

Reinforced Concrete structures are prone to corrosion which is big global problem.The atmosphere containing chloride and more carbon dioxide enhances steel corrosion. Concrete deteriorate and spall faster leading to structural failures . As per Chen 2004, repair cost of concrete infrastructure is around $\$ 100$ billion per annum. Infrastucture growth demands advanced transport systems, Power generations units, disaster management techniques. Designing of concrete infrastructure demands additional load, to ensure safety. Effective combined loads for serviceability to all engineers . Knowledge of Practical observations and experimental experiences says strength of $\mathrm{RC}$ structures is more affected than serviceability .Concrete weak in tension and strong in compression. Cracks developed in the concrete because of additional pressure, leading to longitudinal cracking in reinforcement and concrete. Structures with additional loads start cracking because of this corrosion.

The additional applied loads may exert internal radial pressure on concrete structures. These longitudinal cracks leads to more cracking damaging concrete .It causes public inconvenience .Dedicated research start on corrosion-induced cracking. After studying research it is found that models for cracking of cover concrete for developing longitudinal cracks. This paper explore cracks developed and their relation with enhanced increased

Revised Version Manuscript Received on 16 September, 2019.

SnehalAbhyankar, Department of Civil Engg., V.N.I.T., Nagpur, Maharashtra ,India. pressure and load by calculation .

Research shows methods of finite-element methods for finding factors affecting corrosion. In longitudinal cracking, study stress distribution caused by smeared cracks. These fellows Andrade et al. 1993 did experimental investigations on concrete cracks with accelerated corrosion process to understand cracking in short time did special study on measurement of crack width over time . Empirical models were developed after analysing experimental results.

The factors like concrete cover-to-bar diameter ratios are studied. .Concrete acts as exceptional barrier for containment storage but start leakage once it is cracked After cracking, contaminant leaked into the environment is measured. Flow potential indicates corrosion resistance. While designing life and serviceability of structures main property is corrosion resistance. It shows that concrete when uncracked .

Formulas are studied for leakages in concrete due to corrosion. The thickness of concrete act as insulation for different deterioration caused by fire attack. Resistance of concrete structures to be earthquakes, blasts, fire hazards, and explosion may be studied. Concrete behaves as conductive material for transfer of heat, current, specific thermal capacity. More study required for uncracked section of concrete.

Different materials under different loading conditions behaves unpredictably. To ensure their properties and behaviours aspects of temperature, environment, rate of loading must be studied. This will help to study further fracture strength of concrete, RCC structures to predict their serviceable life. Initially cracks are micro levels, when they enlarge and became macro then consist of energy. This energy upto tolerable limits no issues, but if it overcome the limits, then cracks start converting from micro to macro. If you observe structure you can see macro cracks with naked eyes. Micro cracks further expand by branching inside the structure. .

Regardless of crack form or size, cracks will break the continuity and integrity of a concrete specimen or structure, thereby leading to instability. However, the in this review paper the authors determined that if main cracks have already appeared in concrete, then branching cracks may stabilize the structure by delaying the development speed of large cracks. This phenomenon is interesting. The relationship between formation speed of main and branching cracks should be established to investigate this phenomenon. Traditional methods such as computed tomography, acoustic emission,

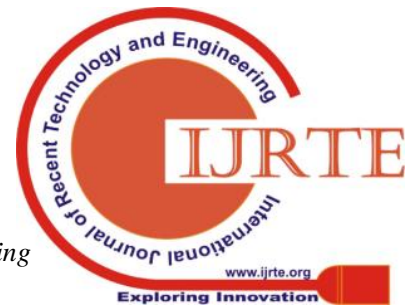


ultrasound, and infrared spectroscopy exhibit limitations in investigating the rapid changes on the surface of a concrete structure. Thus, a high-speed measurement method is necessary. High-speed cameras (HSCs) and ultrahigh-speed cameras (UHSCs) are basic equipment for rapid measurements.

For crack propagation tests, used a HSC and edge detection technology to analyze crack propagation speed in ultrahigh-performance concrete. Yao et al. (2015) added short glass fibers to reinforced concrete to test tension stiffening via aHSC.The width of a crack was captured by the HSC. Five stress-strain curves of the specimen and their characteristic cracks were obtained under different loading rates. Forquin (2012) investigated concrete spalling with a specimen that contained wet and dry saturated concrete.

A strain gauge and UHSC were coupled and used simultaneously.HSC to analyze. UHSC used to record the fracture processes on an oblique surface of a notched semicircular bend specimen under normal and shear stresses. They investigated the microprocess and inner mechanism of rock failure under impact loading based on a SHPB test and recorded the experimental process with a 10,000 FPS HSC.

In the review paper it study, the cracking behaviour of main and branching cracks in concrete is investigated based on a self-made trigger system. Compression tests were conducted on concrete specimens, and a UHSC was used to capture crack formation, crack length, and cracking speed under a compressive load.

Concrete behaves in non linear fashion. The study of analysing and concluding requires accurate methods for crack initiation and propagation. Concrete is heterogeneous aggregates, water, admixtures. Sometimes help of microscopic technology is taken. The formation of cracks starts from surface and slowly penetrate inside. Cracks formed superficially and in the matrix are under study.

RCC structures are subjected to experimental analysis .Sometimes simulation study done on models for understanding pattern of cracks. The structure when subjected to direct forces resist the forces.

\section{DEVELOPMENT OF MODEL}

\section{a. Model Preparation}

Concrete structures are imagined like cylinders having thick wall may be subjected to pressure. How the cylinder will behave is interesting part of study. Stresses caused because of enhances cracking are the main reason of concern. As corrosion penetrates inside concrete, steel inside also corrodes.

Cracks do not penetrate in pores of concrete because of corrosion. Modelling is done for understanding the effects of corrosion. Modelling is also done for materials subjected.

\section{b. Instrumentation}

Concrete specimens are loaded by both the type of loadings. It may be uniaxial or biaxial. It was difficult to measure strains occurring inside specimens. So introduction of strain gauges . They were placed at different levels. Study on different types of cracks on plain and reinforced concrete is done. mixture acting as matrix of coarse aggregates, fine

\section{c. Test Matrix and Set-up}

Concrete specimens are tested for tensile and compressive loading . All specimens received cracks developed by tension.

Specimens dimensions selected to present configurations of structure. Covers for beams, increase to reduce tensile cracks. Specimens were subjected to loads at support and centre. Due cause settlements measured through load cells installed. These results verified by post destructive tests.

\section{RESULT AND DISCUSSION}

RCC structures subjected to corrosion and increased load develops cracks on surface. Structures who subjected o heated analysis can be studied by simulation techniques. The thickness of different specimens were checked and tested under this to give proper concrete strength. The concrete samples who are possessing low strength may develop permeability losses. The specimens having low reinforcement ratio can lead to cracks due to voids. If variable loading then impulsive cracks may develop. Now it can be said that thermal properties do not change strain function as well as crack width.

\section{CONCLUSION}

Tensile cracks developed in concrete may get reduced as there is gradual decrease. More study require to confirm whether this is because some phenomenal changes or some lacking in experimental process. Though this conclusion is valid for this study. Mechanical properties, thermal crack-healing efficiency, temperature, and moisture sensitivity of concrete were studied and compared with those of Portland cement and asphalt concretes. The study of proposed methodology is important for new specification development, in which the performance-based specifications will start to replace the prescriptive ones. Analysis and comparative predictions of results done to summarise the conclusion. The mismatch in the result may be because of variable intensity of loading and inaccuracy of measuring of crack with by strain gauges or displacements of specimens. .

\section{REFERENCES}

1. American Concrete Institute (ACI) Committee 365. (2002). "Service lifeprediction-state-of-the-art report." ACI365.1R-00, American ConcreteInstitute, Farmington Hills, MI, 44.

2. Chen, D., and Mahadevan, S. (2007). "Chloride-induced reinforcementcorrosion and concrete cracking simulation." Cem. Concr. Compos.,30, 227-238.

3. El Maaddawy, T., and Soudki, K. (2007). "A model for prediction of time from corrosion initiation to corrosion cracking." Cem. Concr. Compos.,29(3), 168-175.

4. Xu, G., Wei, J., Zhang, K., and Zhou, X. (2007). "A calculation model for corrosion cracking in $\mathrm{RC}$ structures.” J. China Univ. Geosci., 18(18),85-89.

5. Yuzer, N., Akoz, F., and Kabay, N. (2007). "Prediction of time to crackinitiation in reinforced concrete exposed to chloride." Constr. Build.Mater., 22, 1100-1107.

6. Soppe, T., Stoevhase, M., and Hutchinson, T. C. (2008). "Experimentaldamage-transport correlations for 
uniaxially-loaded reinforced concretewalls." Structural Systems Research Project (SSRP) Report No. 08-07,

7. Univ. of California, San Diego. Soppe, T., and Hutchinson, T. C. (2009). "Experimental damage-transport correlations for biaxially-loaded reinforced concrete walls." Structural

8. Shi, X., Tan, T.-H., Tan, K.-H., and Guo, Z. (2004). "Influence of concrete cover on the fire resistance of reinforced concrete flexural members." J. Struct. Eng., 130(8), 1225-1234.

9. Vejmelková, E., Padevet, P., and Cerny, R. (2008). "Effect of cracks onhygric and thermal characteristics of concrete." Bauphysik, 30(6), 438-444.

10. White, D., Take, W., and Bolton, M. (2003). "Soil deformation measurement using particle image velocimetry (piv) and photogrammetry." Geotechnique, 53(7), 619-631.

11. Al-AbdulWahhab, H. I., Dalhat, M. A., and Habib, M. A. (2016). "Storage stability and high-temperature performance of asphalt binder modified with recycled plastic."

12. West Conshohocken, PA. ASTM. (2015). "Standard test method for flexural strength of concrete (using simple beam with third-point loading)."

13. Azeko, S. T., Mustapha, K., Annan, E., Odusanya, O. S., Soboyejo,A. B. O., and Soboyejo, W. O. (2016a). "Statistical distributions of thestrength and fracture toughness of recycled polyethylene-reinforcedlaterite composites."

14. Babu, G. L. S., and Jaladurgam, M. E. R. (2014). "Strength and deformation characteristics of fly ash mixed with randomly distributed plastic waste." J. Mater. Civ. Eng.,

15. BaghaeeMoghaddam, T., Karim, M. R., and Syammaun, T. (2012)."Dynamic properties of stone mastic asphalt mixtures containing wasteplastic bottles." Constr. Build. Mater., 34, 236-242.

16. Chidiac, S. E., and Mihaljevic, S. N. (2011). "Performance of dry cast concrete blocks containing waste glass powder or polyethylene aggregates."Cem. Concr. Compos., 33(8), 855-863.

17. Colbert, B. W., and You, Z. (2012). "Properties of modified asphalt binders blended with electronic waste powders." J. Mater. Civ. Eng.,

18. Corinaldesi, V., Donnini, J., and Nardinocchi, A. (2015). "Lightweight plasters containing plastic waste for sustainable and energy-efficient building." Constr. Build. Mater., 94, 337-345.

19. Dalhat, M. A., and Al-Abdul Wahhab, H. I. (2015). "Performance ofrecycled plastic wastes modified asphalt binder in Saudi Arabia."Int. J. Pavement Eng., 18(4), 349-35

20. G. O. Young, "Synthetic structure of industrial plastics (Book style with paper title and editor)," in Plastics, 2nd ed. vol. 3, J. Peters, Ed. New York: McGraw-Hill, 1964, pp. 15-64.

21. W.-K. Chen, Linear Networks and Systems (Book style). Belmont, CA: Wadsworth, 1993, pp. 123-135.

22. H. Poor, An Introduction to Signal Detection and Estimation. New York: Springer-Verlag, 1985, ch. 4.

23. C. J. Kaufman, Rocky Mountain Research Lab., Boulder, CO, private communication, May 1995.

24. Y. Yorozu, M. Hirano, K. Oka, and Y. Tagawa, "Electron spectroscopy studies on magneto-optical media and plastic substrate interfaces, $9^{\text {th }}$ Annu. Conf. Magnetics Japan, 1982, p. 301]

25. M. Young, TheTechincal Writers Handbook. Mill Valley, CA: University Science, 1989.

26. (Basic Book/Monograph Online Sources) J. K. Author. (year, month, day). Title (edition)
27. C. Q. Li1 and S. T. Yang, Journal of Engineering Mechanics,Vol. 137, No. 11, November 1, 2011. Experimentally Measured Permeability of Uncracked and Cracked Concrete Components,Tara C. Hutchinson, M.ASCE1; and Travis E. Soppe, P.E., M.ASCE2, Journal of Materials in Civil Engineering, Vol. 24, No. 5, May 1, 2012.

28. Thermal Propagation through Tensile Cracks in Reinforced Concrete, A. Ervine1; M. Gillie2; T. J. Stratford3; and P. Pankaj4,Journal of Materials in CivilEngineering, Vol. 24, No. 5, May 1, 2012.

29. Properties of Recycled Polystyrene and Polypropylene Bounded Concretes Compared to Conventional Concretes, M. A. Dalhat, Ph.D.1; and H. I. Al-Abdul Wahhab2.

30. Early-Age Cracking of Self-Consolidating Concrete with Lightweight and Normal Aggregates Aleksandra Radlińska, A.M.ASCE1; Maria Kaszyńska2; Adam Zieliński3; and Hailong Ye4, Journal of Materials in Civil Engineering, December 12, 2018;

\section{AUTHORS PROFILE}

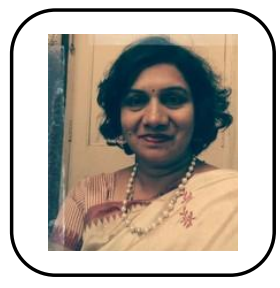

Author is Adjunct Assistant Professor in Visvesarya National Institute of Technology, Nagpur . She is specialized in B.E. Civil Engineering, M.Tech in Structures and $\mathrm{PhD}$ in Civil Engineering (Submitted). She has teaching experience of twelve years and Industrial Experience of 5 years. Her area of interest is Concrete, Concrete cracks, repairs, Fibres, Steel, Smart materials, RCC, Composite materials. 